\title{
Public libraries: adapting to the digitised environment. An interview with John Lake
}

\author{
Por Lluís Agustí y Sílvia Redondo
}

Agustí, Lluís; Redondo, Sílvia. "Public libraries: adapting to the digitised environment. An interview with John Lake". En: El profesional de la información, 2008, marzo-abril, v. 17, n. 2, pp. 236-238.

DOI: 10.3145/epi.2008.mar.16

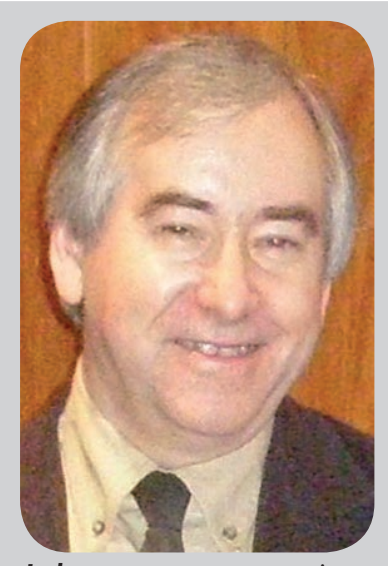

John Lake cuenta con una importante experiencia profesional en el campo de las bibliotecas públicas en Gran Bretaña, y desde 1987 colabora de modo permanente con las secciones de la IFLA relacionadas con la lectura pública. Entre otros reconocimientos, ha recibido el "Public Library Entrepreneur of the Year Award 1999" otorgado por The Public Libraries Group de the Library Association. Actualmente es director de la Barbican Library en la ciudad de Londres y Presidente de la Sección de Bibliotecas Públicas de la IFLA desde 2007.

DURING JOHN LAKE'S VISIT to Barcelona to take part in a seminar organized by the $\mathrm{Fa}$ cultat de Biblioteconomia i Documentació (Department of Library and Information Science) at the University of Barcelona (UB) ${ }^{1}$ EPI sought an interview to further explore some of the themes addressed in the seminar, drawing on his extensive experience in the world of public libraries.

In your lecture you mentioned that "The internet is the most important revolution after the invention of the press". In your opinion, which role has the public library to play in our social and cultural environment? Will bricks still be necessary or just clicks?
- Public libraries will need to be a stimulating combination of the physical and the digital environment for many years to come, in my view. Public libraries are seen as safe, neutral places to be in and people will continue to visit, use and spend time in them as a community space, whether that be to borrow a physical book or other material, study in the library, use the digital resources or to enjoy a cultural event or activity. However, the digitised environment will grow and grow and we must adapt our spaces to cultivate this increasing activity and develop services to complement that growth.

"The digitised environment will grow and grow and we must adapt our spaces to cultivate this increasing activity and develop services to complement that growth"

One of the most important issues for the public library has been to provide free access to information. How should the public library position itself and act in an internet context to select information, provide access to technology, avoid censorship, and secure the liability of the sources?

- Librarians of public libraries should aim to apply the lowest level of censorship or filtering of the internet permissible by the law of the country they work in and thus allow as free as possible access to the information available while providing and applying acceptable use policies to govern the environment which is open to abuse. Just as with any other source of information, librarians have a role and a duty to provide guidance and recommendation of reliable sources which we know to be of good providence and which provide accurate and up to date information.

The Public Library Manifesto of the IFLA starts with the following sentences: "Freedom, prosperity and the development of society and of individuals are fundamental human values. They will only be attained through the ability of well-informed citizens to exercise their democratic rights and to play an active role in society". However it is not always the situation in many countries and for different reasons, mostly political and economic. How do you think the public library and internet could play an active role in this respect?

- I think public librarians need to work within the law and environment of administration of each country which they are governed by, but by providing freely accessible information and being an honest broker of information sources, librarians can assist citizens to make informed decisions about what type of governance is best for themselves, their families, communities and their future. The internet is a powerful information source but also a fragile one in its unreliability and librarians can play a role in assisting citizens to make their choices by training and guiding them through it. 
How do public libraries have to understand and interpret free access in an internet context? What should be the good compromise between free access and copyright? What about music, for instance?

- As with any intellectual property, librarians need to be aware of the ownership and providence of sources of information and digital products on the internet and observe the copyright implications of that when providing any service. Any compromise between free access and copyright needs to be carefully negotiated and agreed with the appropriate industry or owners of the products to allow librarians to provide digitised access to music, art, literature or indeed any intellectual property which they wish to present through their library portals for access or further downloading by the library's users. Some examples of this working already are in the EUA with the MyVideo service, digital dvd services available through public libraries, and in the UK the agreed access to the database of Naxos, the largest recorded classical music company, through public library websites.

Do you think one of the new roles of the public library is to produce information? If yes, could you give us some examples?

- Yes, without doubt, public libraries have a role to collect, record and provide information, although I do not think that this is a new role for many libraries. Community information, local history (especially oral history), guidance to recommended reading, information sources and facilitating the creation of new cultural work through the digitised environment are all areas which I think public libraries have a legitimate role to work with or encourage.

How could public libraries take better advantage of dealing with web 2.0?

- Public libraries are already working in the web 2.0 environment and the use of social networking sites such as MySpace, YouTube and Facebook are just a few environments being used to collect, record and present oral and local history. Web 2.0 provides a platform for libraries to provide blogs and wikis on areas of interest to their users and record visual databases on platforms such as Flickr. Web 2.0 also provides a good opportunity for librarians to market their services and keep their users informed through rss feeds and podcasts of news or events concerning their services. In the arena of catalogues and databases, the use of metadata, folksonomies and tag clouds can make the searching of library catalogues and databases on the web much more powerful and user orientated. These are but a few examples -the possibilities are only limited by our imaginations, and of course corporate ICT policies!

\section{"I believe librarians need to be excellent communicators in every sense of the word"}

Technology progress goes extremely fast. Which qualities, technical and personal, do librarians have to develop in order to follow this challenge?

- I believe librarians need to be excellent communicators in every sense of the word, energetic and wise advocates and leaders of their service, and good managers of people and resources to rise to the challenge of the future development of public libraries. Technical expertise will inevitably be centred on information and communication technology (ICT) skills and the use of the world wide web, but our ability to analyse, organise and disseminate information will still be the centre pin of our technical skills, as it has been in the 20th century.
What kind of "new" actions or projects have you undertaken in your Library that could be useful for other libraries?

- I introduced a stock security and management facility using RFID technology in 2004. The Barbican Library was the second public library in the UK to use this technology, which is capable of very fast transactions using radio frequency to read information from a tag placed in a book. This allows books and other items to be loaned by users on a self-service basis without having to open the book and scan a barcode. This means that a large pile of books can be issued by simply placing them on a pad, which reads through all the covers and records the data. It also provides the capability for stock management, including stock inventory, without having to remove books from the shelves and facilitates item searching and shelf tidying.

My library also offers online access to many electronic resources for users from their home computer or laptop. All members need to do is enter their membership number on the relevant website to log into a huge range of reference resources that would otherwise require a payment.

Because of your position in IFLA you know many public libraries in a large number of countries. In your opinion, what is the situation of public libraries in Spain in the European context? And where do you think they are more developed?

- I have been fortunate to visit many libraries in many countries but actually have not had the opportunity to visit any in Spain apart from Barcelona city and province. I have found that the library services there have a very forward looking approach, using IFLA Guidelines and Standards to help improve their services and this is particularly evi- 
dent in the excellent new buildings programme, for example, where modern design techniques are being used to bring library services to communities, fusing the traditional printed services with digital environment. The approach to marketing and presentation of services is also well advanced with well designed and aesthetically pleasing publicity. I am also aware of plans in hand to extend their online services into the web 2.0 environment, which will allow far more interactivity in the provision of their web services.

\section{Nota}

1. El texto en inglés de la conferencia de John
Lake está disponible en la web.

http://www.ub.edu/biblio/aula/seminaris/public_ library2010.pdf

Lluís Agustí, Silvia Redondo, Facultat de Biblioteconomia i Documentació, Universitat de Barcelona. agusti@ub.edu redondosil@gmail.com

\section{Suscripción EPI sólo online}

Pensando sobre todo en los posibles suscriptores latinoamericanos, ya no es obligatorio pagar la suscripción impresa de EPI para acceder a la online.

EPI se ofrece a instituciones en suscripción "sólo online" a un precio considerablemente más reducido (85 euros/año), puesto que en esta modalidad no hay que cubrir los gastos de imprenta ni de correo postal.

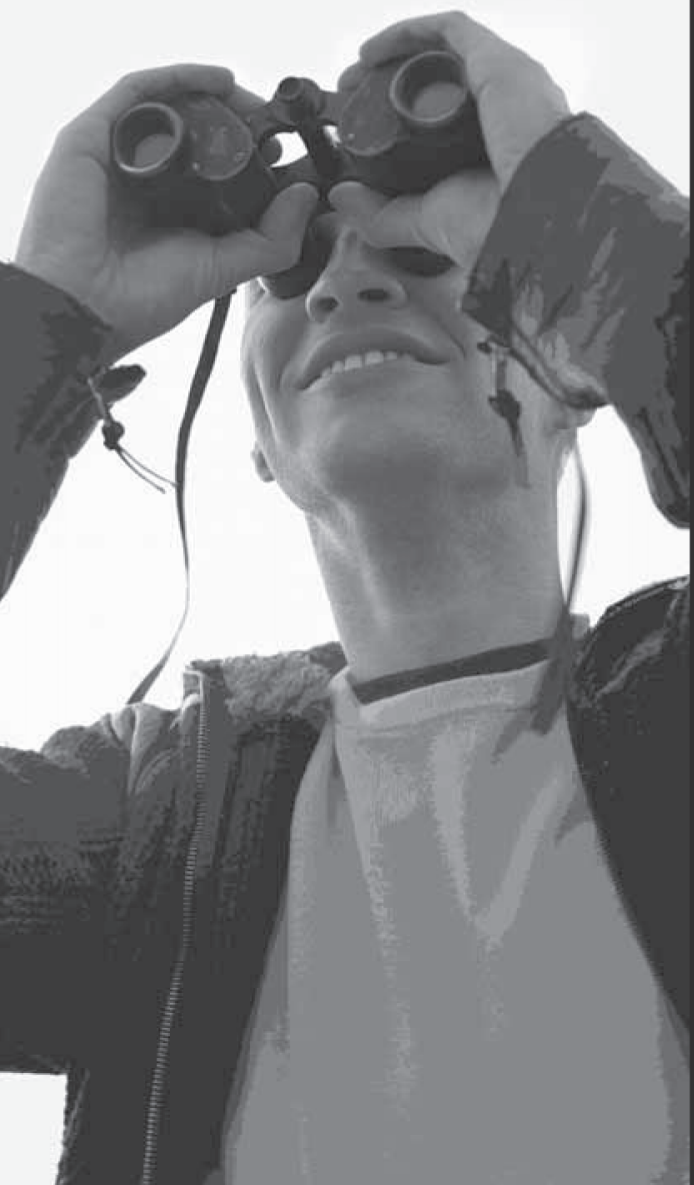

\section{MÁSTER EN DOCUMENTACIÓN DIGITAL}

\section{Máster y Programas de posgrado online}

Arquitectura de la información en sitios web. - Organización de la información y sistemas de gestión de base de datos. - Buscadores y posicionamiento web. - Documentación audiovisual. - Web 2.0 (nuevo). - Archivística digital. . Gestión de contenidos y gestión del conocimiento. • Bibliotecas digitales. Repositorios y bibliotecas digitales (ampliado).. Usabilidad.

Dirección: Cristòfol Rovira y Lluís Codina

Calendario: del 9 de octubre de 2008 al 30 de junio de 2009 www.documentaciondigital.org

\section{MÁSTER EN BUSCADORES MARKETING Y POSICIONAMIENTO}

Máster y Programas de posgrado online

- Fundamentos. - Posicionamiento en Buscadores. - Marketing en Buscadores. - Vigilancia Tecnológica. . Recuperación de la Información.

- Buscadores especializados.

Dirección: Cristòfol Rovira y Lluís Codina

Calendario: del 13 de noviembre de 2008 al 30 de junio de 2009.

www.masterenbuscadores.com

\section{Colaboran:}

Observatorio de Comunicación Científica - UPF Instituto Universitario de Lingǘstica Aplicada - UPF DOC 6 Consultores de Recursos de Información 